\title{
Evaluation of the Self-regulated Learning Model in High Schools: A Systematic Literature Review
}

\author{
Ameliasari Tauresia Kesuma ${ }^{1, *}$, Harun $^{1}$, Zamroni $^{1}$, Himawan Putranta ${ }^{2}$, Hanif Cahyo Adi Kistoro ${ }^{3}$ \\ ${ }^{1}$ Department of Educational Research and Evaluation, Graduate School, Yogyakarta State University, Indonesia \\ ${ }^{2}$ Concentration of Physics Education, Department of Education, Graduate School, Yogyakarta State University, Indonesia \\ ${ }^{3}$ Department of Islamic Education, Faculty of Islamic Religion, Ahmad Dahlan University, Indonesia
}

Received July 10, 2020; Revised August 7, 2020; Accepted September 11, 2020

\section{Cite This Paper in the following Citation Styles}

(a): [1] Ameliasari Tauresia Kesuma, Harun, Zamroni, Himawan Putranta, Hanif Cahyo Adi Kistoro, "Evaluation of the Self-regulated Learning Model in High Schools: A Systematic Literature Review," Universal Journal of Educational Research, Vol. 8, No. 10, pp. 4792 - 4806, 2020. DOI: 10.13189/ujer.2020.081051.

(b): Ameliasari Tauresia Kesuma, Harun, Zamroni, Himawan Putranta, Hanif Cahyo Adi Kistoro (2020). Evaluation of the Self-regulated Learning Model in High Schools: A Systematic Literature Review. Universal Journal of Educational Research, 8(10), 4792 - 4806. DOI: 10.13189/ujer.2020.081051.

Copyright@2020 by authors, all rights reserved. Authors agree that this article remains permanently open access under the terms of the Creative Commons Attribution License 4.0 International License

\begin{abstract}
Self-regulated learning (SRL) is used to learn things that affect student learning and learning outcomes. This research type is review research, which critically examines and sees the application of the SRL model in Indonesia. The criteria taken in this review research are learning models that have a theoretical and practical foundation. The learning models analyzed include learning models from Boekaerts; Winne; Zimmerman; Efklides; Hadwin, Järvelä and Miller; and Pintrich because it was used as a basis for various SRL studies. Each learning model is explored in detail, including a description of the model, a practical foundation, and instruments built on the model. After that, the learning model is compared with a number of aspects in each phase, so a newer and simpler learning model synthesis appears. The empirical evidence from the SRL meta-analysis was raised regarding the evaluation of the model. The SRL model can improve students' SRL skills, especially students who are still dependent on the teacher's role. Therefore, it is necessary to categorize students before applying the SRL development model consisting of goals, strategies, and reflections. Teachers should have various lists of SRL models, so they can adjust their interventions to improve these skills more effectively.
\end{abstract}

Keywords Learning Outcomes, Meta-Analysis, Metacognition, Self-regulated Learning, Strategies

\section{Introduction}

Self-regulated learning (SRL) is a skill that is closely related to the way students regulate emotions, cognition, behavior, and aspects of their environment during learning. The better the student's SRL, the easier it is to interpret what it learns, the more mature its character, and the more its learning outcomes [1]. The rapid development in the field of science and technology is not enough to be responded to by various educational policies. The 21st Century Competencies (21CC) framework emerged as an effort to improve and reform the education system in order to prepare students to become effective human beings, as well as to solve all the complex problems they face [2]. The competencies and skills needed by students in facing their world in the 21st century are emphasized on seven skills. Critical thinking skills, collaboration and leadership, dexterity and adaptability, initiatives, and entrepreneurial spirit, communicating both verbally and in writing, interpreting the information obtained both and having good curiosity and imagination [3].

Zimmerman in his research stated that growing competencies and skills needed in the 21st century was one of them by equipping students with SRL skills [4]. Theoretically, SRL is the basis for giving instruction, tasks that can be done effectively and efficiently at various academic levels, for a variety of students and subjects, which are proven able to improve their academic results [5]. Students, who have high SRL, can do assignments, projects, 
and tests very well, essays either test [6]. SRL becomes an important topic in education because it has an important component that supports students becoming lifelong learners in the 21st century. SRL makes students trained to be active, independent, become problem solvers, think critically, innovatively, become students who have a good social outlook [7]. The results show that SRL strategies that have been carried out in various places and at various levels have been shown to correlate with student academic performance [8].

Furthermore, students can be described as students who are SRL if they have metacognitive abilities, motivations, and active participants in their learning activity [4]. Metacognitive is defined as the decision making process of various knowledge choices. SRL students must have a strategy to achieve their learning goals based on self-efficacy perceptions with the assumption that students have independent learning strategies, self-efficacy, and commitment to their learning goals [4]. SRL is related to oneself and one's ability to try, control oneself, and critically evaluate themselves to achieve the best results and about how to overcome risks, failures, disturbances, fight laziness in pursuing life goals [9]. SRL in the classroom is how teachers and students discuss learning goals, ways of learning, and how they measure learning success.

As stated by Ki Hajar Dewantara, the right learning process places students as teachers who control and are responsible for the learning process, and the teacher plays the main role as students who learn sensitive and meet the needs of students [10]. Therefore, a deeper understanding of the SRL process is needed. Where basic and teaching work together to find the best learning for students. The teaching referred to is education and teaching and basis in question is aptitude [11]. Basic and teaching are the concept of educating by harmonizing the teaching material with students' aptitude [12]. Independent learning in Indonesia began and developed since 2015 and stakeholders agreed to use the term independent learning which will later become the basis of the cultural education program in 2019 [13].

Furthermore, the concept of SRL developed in Indonesia includes three things, namely learning objectives, effective learning methods, and reflection. The emphasis of SRL in Indonesia is more on teacher strategies to improve the SRL skills of Indonesian students [14]. Moreover, to facilitate the understanding of concepts, in this article the term SRL is used as the core theory of developing SRL in Indonesia. Not many scientific studies have even been conducted on the development of this SRL model. Therefore, it is necessary to know a variety of SRL models that have developed a lot and then arranged theoretically analyzed what kind of models are suitable for the context of Indonesian students. SRL is a conceptual framework for understanding aspects of cognitive, motivational, and emotional learning [15].
SRL has made a big contribution to psychology and education since researchers began to distinguish between SRL and metacognitive [16]. Since that time, research began to emerge on the theory of SRL and conceptual development, and finally a model of SRL emerged [17]. Furthermore, a review conducted by researchers was theoretically published in 2001 [18] it included the appropriate model at the time, the SRL model from Boekaerts; Win; Zimmerman; Efklides; Hadwin, Järvelä and Miller; and Pintrich. However, after 2001 studies on this subject developed massively. It can be shown that there are currently three categories of meta-analyzes of the influence of SRL [19]. Other points can be demonstrated by the existence of a SRL model in the realm of education and psychology [20].

Moreover, various methods are determined for evaluating SRL [21]. Compared to previous studies, the handbook does not have a part that is applied in showing new models, which focus on certain parts of SRL (for example, background, teaching problems, methodological problems), which indicate that this realm has evolved. This article tries to review about SRL based on the development of the SRL model to be extracted and then simplified to be applied in Indonesia. Therefore, the purpose of this review is to analyze, compare and evaluate SRL models in accordance with the latest conditions and available new empirical data relating to students' readiness to face government SRL programs.

\section{Literature Review}

\subsection{The Concept of Self-regulated Learning (SRL)}

SRL theory focuses on the way students can be active, change, and maintain their ways of learning and how they relate to their social environment, in the context of formal and informal teaching [4]. Learning is not something that directly appears in students, but things that arise by students and scientists who state that for learning to emerge, students must be active and participatory [4]. SRL is active and participatory process of students to obtain academic ability, the proactive process, for example, setting goals, having an appropriate strategy, and monitoring the process of implementing the strategy to see its effectiveness [22]. Recent research reveals many aspects of SRL that highlight the need to learn this in real terms, as an aptitude [23]. Aptitude is an absolute characteristic and measurement of this ability can be used to determine the individual in the future. Therefore, the metacognitive and cognitive perception of a person becomes an accurate measurement of SRL.

SRL as an innate aptitude can be measured through quantitative methods such as self-report questionnaires [23]. SRL is an activity, a constructive process in which students create their learning goals and in the process of 
achieving those goals. Students monitor, regulate, control cognitive abilities, motivation, and behavior and are all limited to the learning goals that have been set and the learning environment [24]. Bandura defines SRL as the ability to control their own behavior. Bandura proposes three steps of self-regulation, self-observation, we see ourselves, our behavior, and guard it. Decision (judgment), comparing what is seen with a standard. Self-response, if we are better in comparison with our standards, we give ourselves an answer to self-respect [25]. Pintrich argues that SRL is an active, participatory, and constructive activity, with students setting their own learning goals and monitoring, controlling their cognitive, and their behavior, all of which are facilitated by real goals and problems that occur in their environment [22].

Students in SRL are active students who are able to implement their learning experience in a real field with a variety of methods, such as developing a conducive work climate by utilizing existing resources so as to create high productivity. Information understanding as a source of learning, being able to control emotions in learning, and keeping some motivation [26]. Pintrich argues that SRL is an active, participatory, and constructive activity, with students setting their own learning goals and monitoring, controlling their cognitive, and their behavior, all of which are facilitated by real goals and problems that occur in their environment [27]. Based on the various expert opinions, it can be synthesized SRL is how students have an awareness to set their own learning. Moreover, starting from the learning objectives to be achieved, the way these students achieve their learning goals, and how students reflect to evaluate whether the process they made is effective to achieve the learning goals he set himself. The results of students depending on the learning environment and student level, the better and support the learning environment, the ability of students to make self-regulation the better, as well as the higher the age of the student, the more he realizes his learning needs, the better he organizes his learning.

\subsection{Self-regulated Learning Model}

SRL is a conceptual scheme for understanding cognitive, metacognitive, behavior, motivation, and affective aspects of learning. Therefore, a large number of variables that influence learning (self-efficacy, willpower, cognitive strategies) are studied in a comprehensive and holistic approach. Therefore, SRL becomes one of the most important research fields in psychology and education. Based on its popularity or a model that is often used and cited, there are four SRL models, which are as follows.

\subsubsection{Zimmerman (A Socio-Cognitive View as the Theoretical Basis of Self-Regulated Learning)}

Zimmerman is the first initiator of SRL, three SRL models developed are Triadic models, SRL through three phases, namely forethought, performance, and self-reflection [4]. SRL Social cognitive conception involves the triadic analysis of component processes and assumptions of causality between personal, behavior, and environmental triadic influences as presented in Figure 1.

SRL researchers in the classroom, which are governed by the curriculum, have begun to learn the process by which students begin and direct their efforts to gain knowledge and skills. SRL's social cognitive conception includes a triadic analysis of the component processes and assumptions of causality between personal, behavior, and triadic influences in the environment in which the individual is located. This periodically places a central role in building academic self-efficacy beliefs and three self-regulation processes namely self-regulatory process, self-observation, and self-judgment. The social-cognitive formulation in triadic is very useful for increasing student academic achievement and student ability [4]. Meanwhile, the Cyclical Phases model proposed by Zimmerman can be presented in Figure 2.

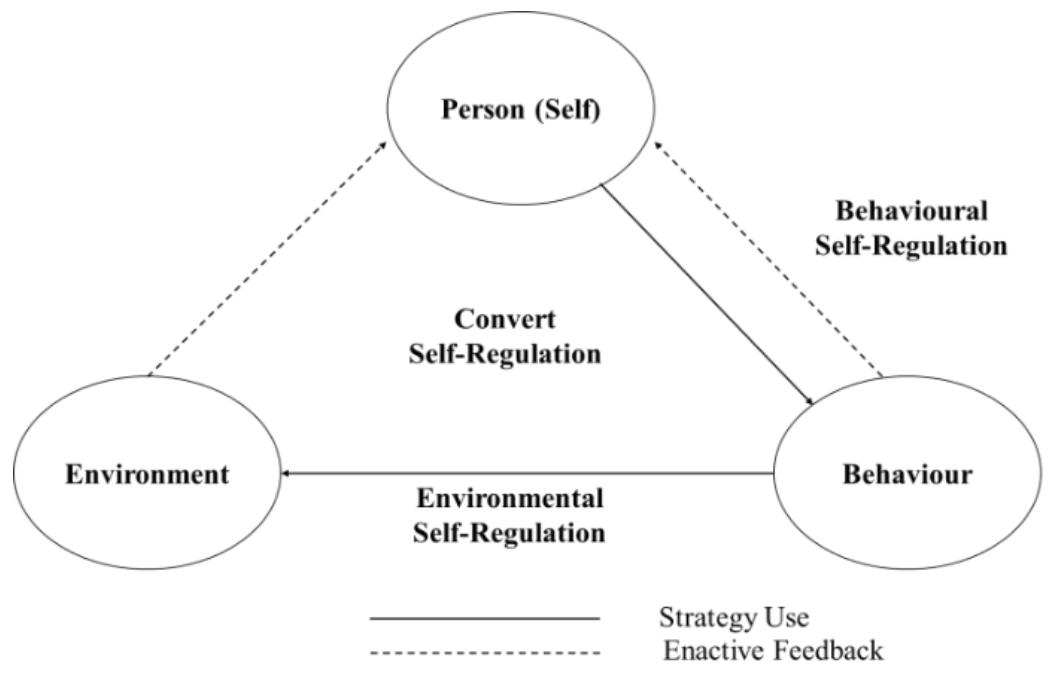

Figure 1. Triadic SRL Model by Zimmerman 


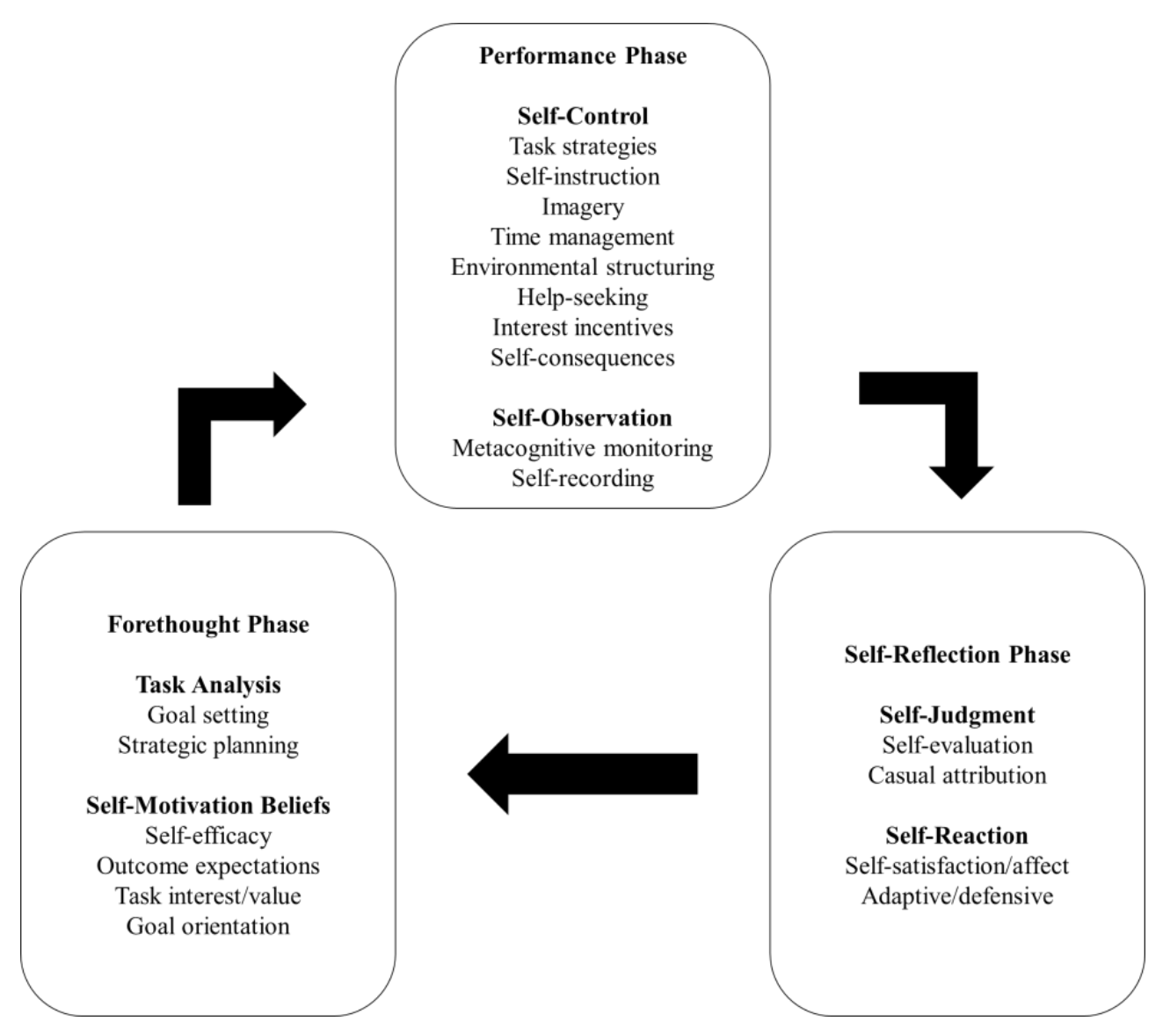

Figure 2. Cyclical Phases Model by Zimmerman

In the forethought phase, students assess their assignments as students and set goals for completing the given assignment [28]. However, when students learn new chapters, they mostly have difficulty in completing assignments given by the teacher. Teachers and/or peers who are more experienced can provide interventions on ways that can be done to complete the task. In the next phase of performance monitoring, students use strategies, monitor their effectiveness, and motivate them to complete their assignments according to the goals they have set. When new strategies are applied, students usually return to using old strategies that are often used even though they may not be effective. For example, students use flashcard strategies to learn vocabulary, even though the teacher has provided alternative strategies that are more effective. In fact, taking the time to practice using a new strategy helps students get the meaning of the task they are doing, rather than using an old strategy that is less effective. The supervision and feedback provided by the teacher can make it easier for students to learn to use new methods effectively [29]. The final phase is a reflection of the performance phase; students review the learning performance they have done, among other things, about the effectiveness of the tactics they use. In this phase, students must also control their emotions. Self-reflection then affects the planning and learning objectives of the next student.

\subsubsection{Boekaerts (Roadmaps Different Objectives: Top-Down/Bottom-up and The Role of Emotions)}

Boekaerts also included the initial initiator of SRL, his research focusing on student learning goals for SRL, for example, how students determine various learning goals. Boekaerts was the first to implement steps to evaluate students' SRL motivation. Boekaerts has featured two SRL models. First, Boekaerts found a structural model, individual self-regulation is divided into six parts, knowledge and skill domains, cognitive tactics, individual self-regulation tactics, cognition, motivation, motivational tactics, and individual self-regulation motivational tactics [30]. What is then often called, two basic mechanisms of SRL, cognitive self-regulation, and motivation? This model is implemented to get more diverse information about the detailed components of the SRL domain, provide training to teachers, develop measurement instruments, and develop intervention programs [31]. Furthermore, the six components of SRL sparked by Boekaerts can be shown in Figure 3 below. 


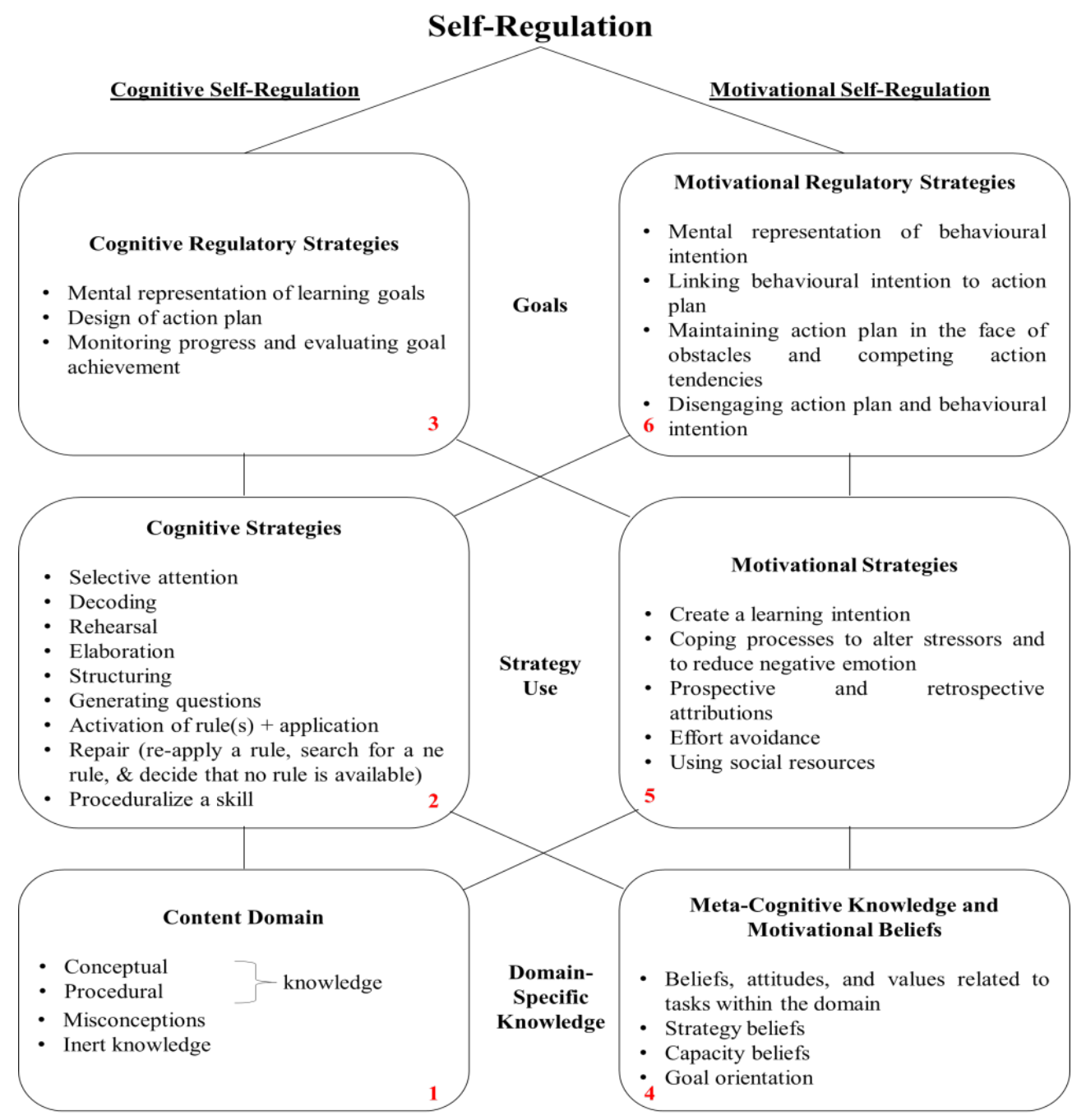

Figure 3. Six Components of SRL by Boekaerts

Description of the dynamic aspects of SRL, and developing into a Dual Processing model of SRL. Adaptable learning models offer a theoretical foundation to interpret findings from a variety of psychological frameworks, including self-concept, metacognition, emotions, motivation, and learning. The following SRL model describes two mechanisms in parallel processing, namely the mastery learning mechanism, and the sustainable coping mechanism. Various new ideas found on the goal track use different numbers to visualize how they affect student behavior [32]. Nevertheless, Boekaerts had presented several ideas about his vision of top-down and bottom-up theory, this theoretical insight was clearly defined in his model, which was later named as dual processing SRL [30].

\subsubsection{Winnie and Hadwin (Exploring SRL from a Metacognitive point of view)}

This model has four phases [33], the first is the task definition of students conducting a survey to understand the assignments given and the objectives they want to achieve because this will affect their learning outcomes. This Winnie model distinguishes between internal and external cognitive. Internal motivation includes students' self-efficacy, orientation to learning goals, knowledge and skills related to the task to be carried out, metacognitive knowledge about when and why applying learning strategies as well as other relevant knowledge. An external situation is how students recognize the learning environment that influences the learning strategies taken [34]. This external and internal situation will provide enough information for students to move on to the next phase. In the second phase of goal setting and planning students, begin to set operational goals in order to obtain good and precise assignment results. This goal then becomes the standard for monitoring whether the processes and strategies taken are sufficient. The strategy chosen uses the "if-then" rule - if the task is obtained, as this then certain cognitive operational strategies will then be used.

The strategy taken is said to be good if it is easy to implement, it can be seen how the product is produced later, and the efficiency of time until the product is completed. 
Armed with these goals and strategies students enter phase 3. In phase three the enacting study tactics and strategies students monitor whether the strategies taken are appropriate whether there are differences in implementation with what is expected if there are differences in metacognition controls can be made to make adjustments in the next phase. In the fourth phase, metacognitive adapting studying students consider making the necessary adjustments to what happens with their projects in the future. Each phase element can be used as the target strategy that is taken. Winnie and Hadwin consider SRL everywhere, not a learning approach that can be raised. Recursion is the main key to this model, that is, products produced in any phase can be put back into that phase to be perfected. Another thing to note is, usually the phases are carried out sequentially, and this model allows students to be able to rewind phases. Furthermore, the SRL model proposed by Winne and Hadwin can be shown in Figure 4 below.

In addition, SRL involves five different aspects of the task, which can occur in the four phases. These five aspects were identified using the COPES acronym, namely Conditions, existing resources for individuals, and problems that arise in a task [35]. Students use operations, cognitive processes, tactics, and strategies referred to as SMART (Searching, Monitoring, Assembling, Practicing, and Translating) [36]. Product, information obtained from the strategy taken. Evaluation, feedback about the suitability between standards product and produced internally by students. Furthermore standards, criteria by which the product is monitored [31]. This Winne \& Hadwin model has the potential to influence how researchers can understand the event of learning. This model is relatively stable between conditions, operations, and products or in other words between the conditions of the tasks given, the strategies taken and the new knowledge gained, but this related is highly dependent on the various types of students' character, how they go through the four phases of this model.

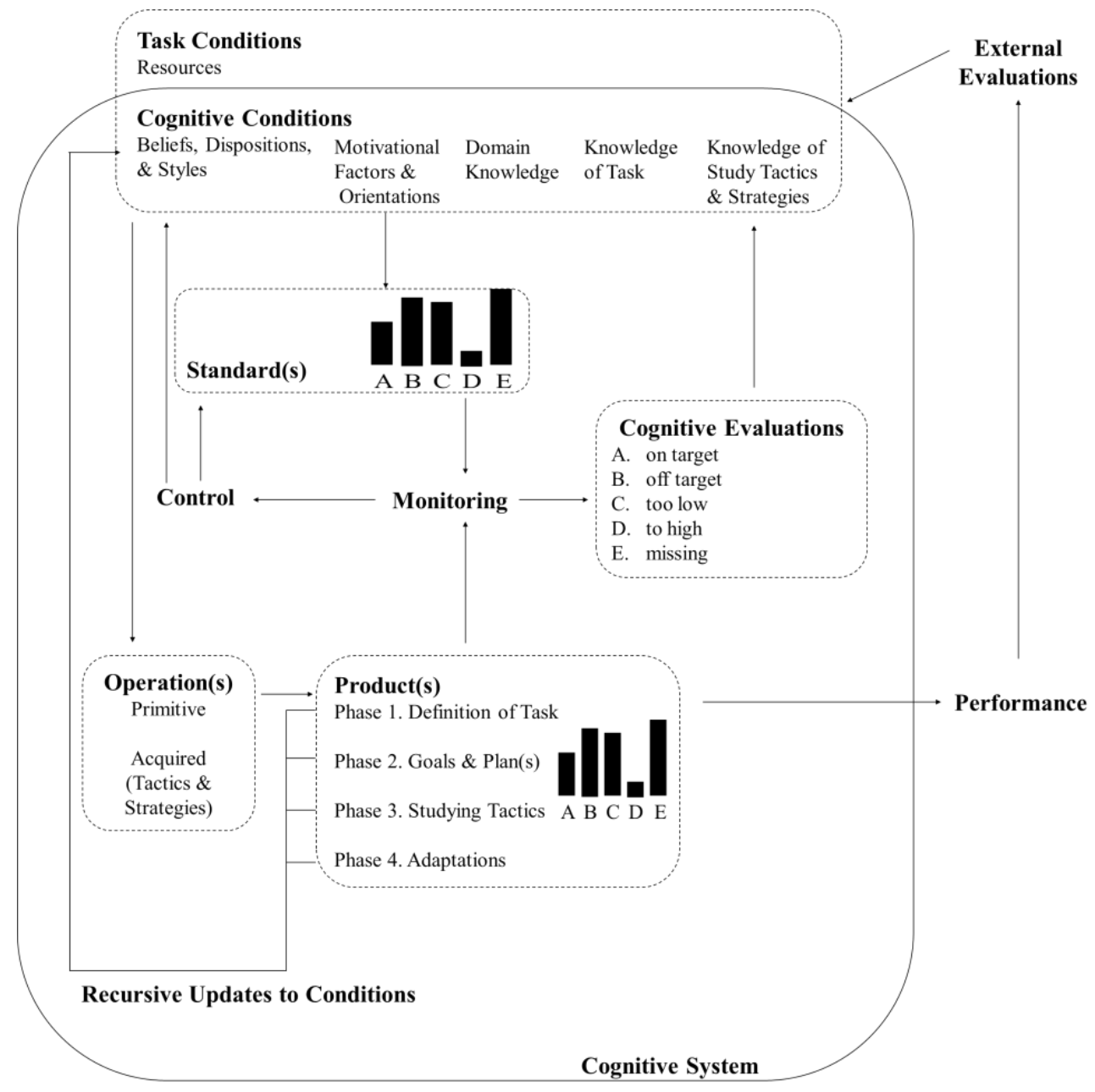

Figure 4. Winne's SRL Model by Winne and Hadwin 


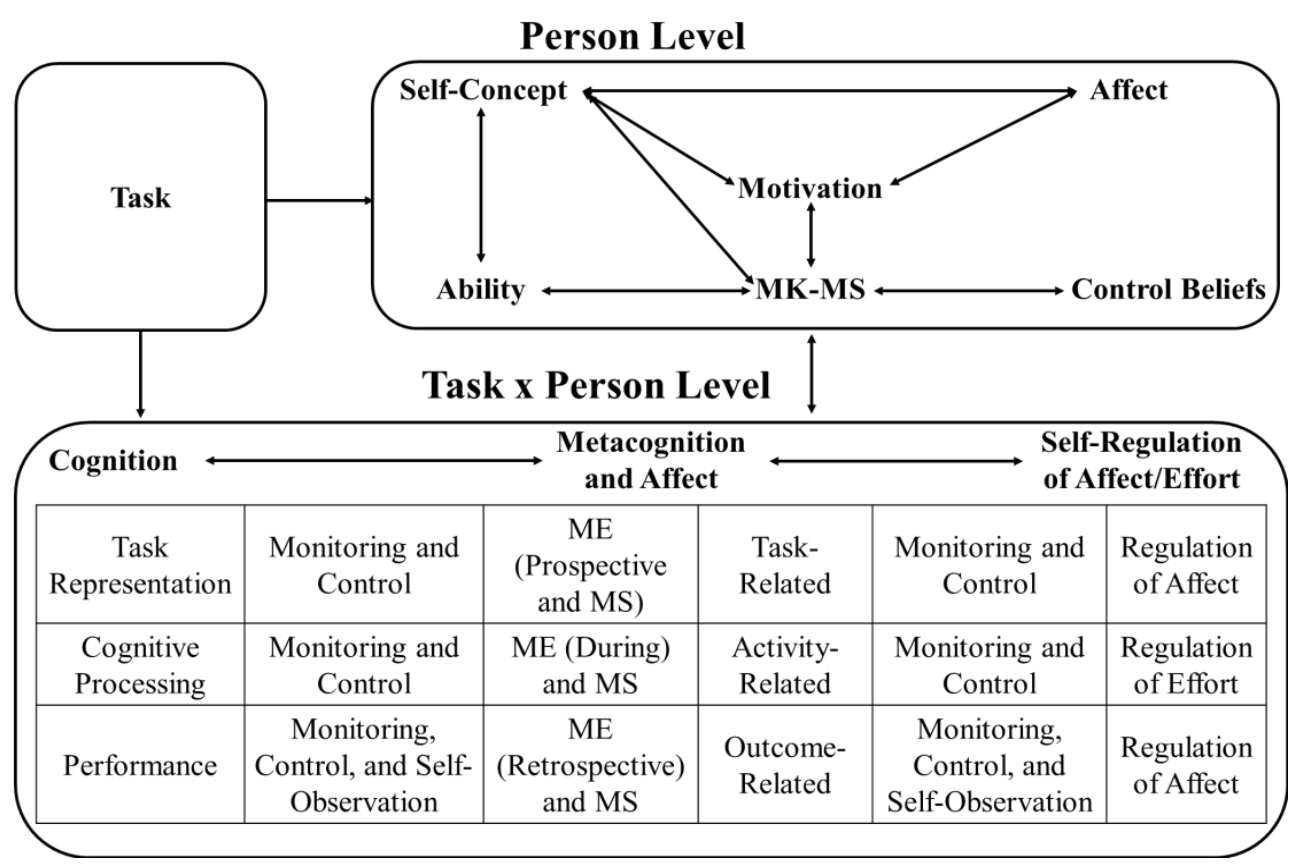

Figure 5. The Metacognitive and Affective Model of SRL Model (MASRL) by Efklides

\subsubsection{Efklides (Missing Part of Metacognition and SRL)}

The Efklides model has a stronger metacognitive foundation than other SRL models, except Winne and Hadwin [37]. However, when compared with others, motivation and affective have a central influence. The Metacognitive and Affective Model of SRL (MASRL), has two tiers as shown in Figure 5 above.

Based on Figure 5, there are two tiers in the metacognitive and affective model of SRL (MASRL). First, there is the Person tier/level which is also called the macro tier. This tier is a "traditional" view of SRL and understands students' personal characteristics. Efklides model consists of cognition, motivation, self-concept, affect, will, metacognition in the form of metacognitive knowledge, and metacognition in the form of metacognitive skills. Efklides consider the Person tier to be top-down because it is organized based on students' goals for the assignment. In other words, the impulse of this set goal guides students through the cognitive process and the effort they will make, students will make decisions based on the interaction of one's competence, self-concept in the task domain, motivation, and influence, task perception and demands [38].

The second tier/level is the task level $\times$ People also known as micro-level. This level is the level of interaction between task types and student characteristics. This level is structured from the ground up because metacognitive activities control student actions, which cause activities to be "data-driven" with a focus on handling the demands of certain tasks. Put simply, students' attention moves toward specific mechanisms for doing tasks, and general learning goals (for example, completing summaries) are included in more specific goals (for example, checking spelling errors).
Here, micro-level supervision is the main thing; Motivation and reaction effects are related to the evolution of metacognitive resources and feedback that comes from individual performance if the individual is able to develop properly. Therefore, Efklides put forward four basic functions namely cognition, metacognition, influence, and regulation of influence and effort, which can be conceptualized independently as shown in Figure 5 . Differences between levels of People and Task $\times$ Level people are perhaps the most prominent features of the MARSL model. The Level Person represents the feature-oriented nature of the general SRL student, which is driven by purpose and from the top down. At this level, the MASRL model resembles the model that was coined by Zimmerman. At the Task $\times$ Person level, the actions that occur are unconscious and oriented towards other individuals: task implementation occupies most of the attention and processing of students, and those actions are driven by data and from the bottom up, showing similarities with Winne's.

In general, the MASRL model explains in detail the related between motivation, metacognition, and influence through macro and micro-level interactions, and presents different conceptualizations of the top-down/bottom-up implications [39]. This model also describes the method used by students in completing assignments given by the teacher, the phase that has the greatest cognitive is when cognitive resources control activities. There are two instruments that reflect aspects of the MASRL model. First, Efklides invented a questionnaire to measure self-concept in language subjects. These findings compare students' language performance with the four categories reported: self-perception, self-efficacy, self-esteem, and perception 
of their abilities. The interaction of these components is a major aspect of the MASRL model because, for example, individuals interact at the Person and Person $\times$ task level with metacognition. Second, Efklides invented the metacognition experience questionnaire, which examines judgments and feelings about cognitive processing. This study aims to determine the relationship between experience and metacognitive performance, and the effects of task difficulties on metacognitive experiences.

\subsubsection{Hadwin, Järvelä, and Miller (SRL in the Context of Collaborative Learning)}

The SRL model found by Hadwin, Järvelä, and Miller discusses the related and influence of SRL in collaborative learning. The SRL model found by Hadwin, Järvelä, and Miller can be shown in Figure 6 below.

Based on Figure 6, it can be seen that this model apart from the superiority of collaboration supported by technology assistance for learning, collaboration raises challenges, barriers to cognitive, motivation, and the environment [40,41]. In addition, to collaborate effectively, each individual needs to commit to one another, build a common foundation, and deliberate and share tasks in completing tasks, strategies, and goals. In other words, each individual needs to share their learning rules (Share SRL-SSRL). The fundamental problem in SSRL is that this model develops and combines individual and social processes, and cannot be reduced to the individual level. SSRL is a field that was recently developed at SRL. Therefore, the model proposed by Hadwin, Järvelä, and Miller (hereinafter referred to as the SSRL model). Furthermore, measurement instruments in the form of questionnaires are no longer used, although there are studies in the field using self-reported data [37]. This is due to the fact that SSRL has discovered contextual characteristics that are interpersonal learning procedures.

\subsubsection{Pintrich (Emphasis on Motivation in SRL)}

In the Pintrich Model [36,42] there are four areas that affect students' SRL, namely, cognition, motivation, behavior, and context. These four factors are combined with the four phases in the Pintrich model namely forethought planning and activation; the second phase of Monitoring; the third phase of control and the fourth phase of reaction and reflection. This combination of phases and areas comprehensively provides an overview of the process of SRL in detail how different components or areas of SRL are explained in this phase of the Pintrich model [16]. In the first phase, students begin to identify their learning goals, create a timeline, make perceptions about the tasks given, and determine motivations that affect their work [43]. In the cognitive area, they estimate how the results of a given task, activate their previous knowledge is also associated with a variety of knowledge they acquire (metacognitive knowledge), then determine the final destination of the given task. The process in the area of motivation involves the students' efficacy to use knowledge, both cognition, and metacognition, to carry out the given task, including the difficulties that may be encountered in the process of carrying out the task, so as to determine the desired outcome. In the area of student behavior, consider how they allocate time and effort as well as collecting data needed to complete the task. Students also check whether contexts such as instructions from teachers are clear and can be carried out [36]. 


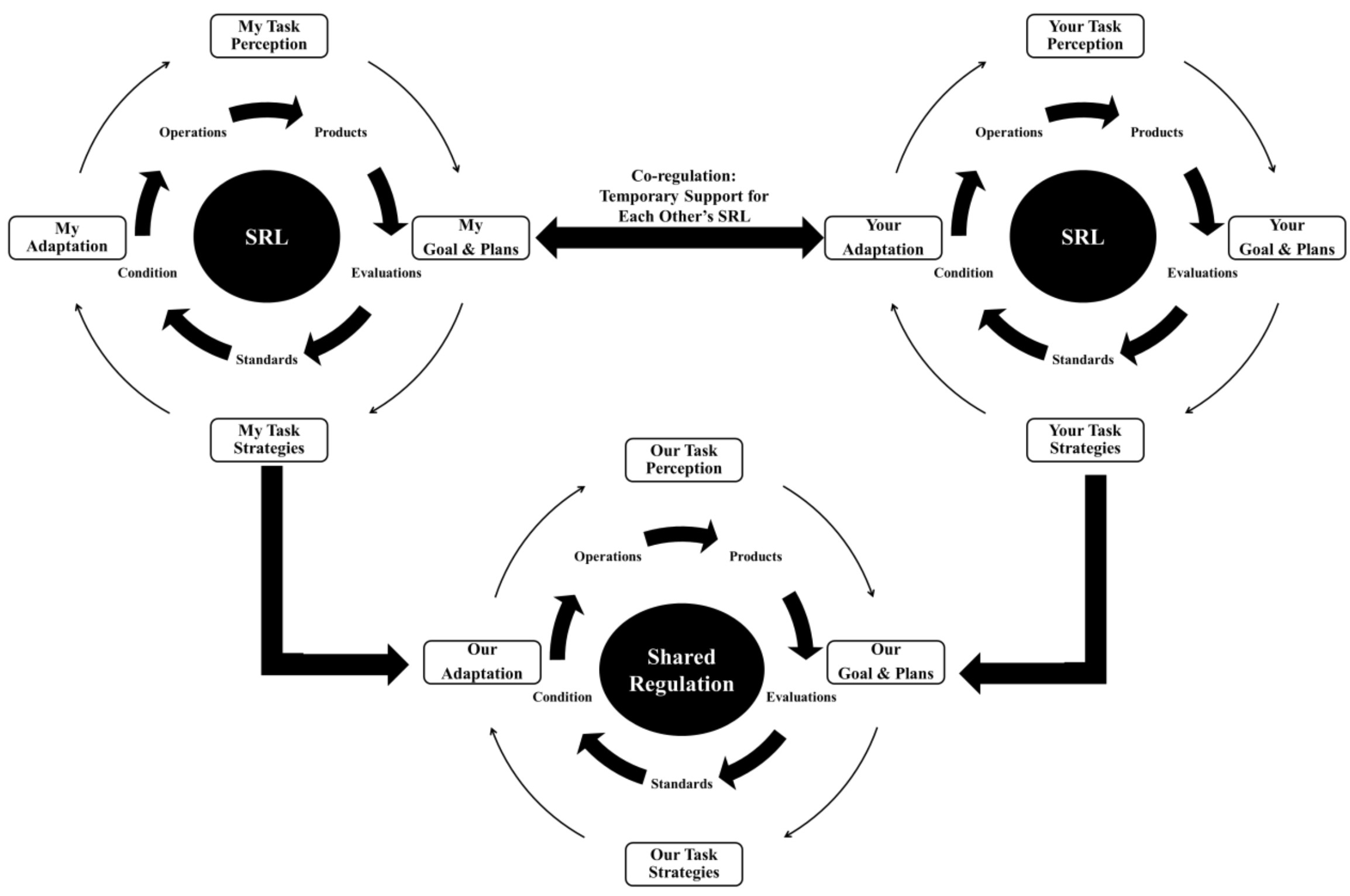

Figure 6. Socially Shared Regulated Learning Model by Hadwin, Järvelä, and Miller 
The Pintrich phase 2 model is monitoring. In the cognitive area, assessment of learning and feelings to know is considered. Areas of motivation that are monitored are changes in expectations of success, as well as things that explain the progress of tasks and emotional reactions. The area of student behavior looks at whether the time specified is appropriate in the implementation, what are the obstacles that occur. Then in what context does the change occur. Phase 3 controls all four areas. For example, if learning is rated below standard, students can decide to review content, adjust expectations of efficacy, revise ratings of difficulty, and seek additional material. In the fourth phase, students react and reflect on their experiences while working on the task as a whole. Once again, each category of regulation is considered. Cognitively, students may realize that they fared better by activating a wider sample of knowledge. In the area of motivation, they can associate the activation of their knowledge as an explanation for why it is not in accordance with the predetermined time target. In the area of behavior, time may be considered more important and, in the contextual category, it can be noted that asking teachers to be clearer about how parts of the task can allocate time better. In this phase, it is seen how the specified target is reached, if not where the deficiencies are, why not according to the target time. Furthermore, the SRLmodel initiated by Pintrich can be shown in Table 1 below.

SRL includes cognitive, metacognitive, motivational, emotional, and learning aspects, therefore there are many variables that greatly affect learning, such as self-efficacy and cognitive strategies that are studied both comprehensively and holistic. The better students have SRL, the easier it is for students to understand what they are learning [43]. Therefore, SRL becomes one of the important research areas in educational psychology research. This article looks at how SRL models compare, how they can be applied in practice, and what their implications are. The research question to be answered in this research is how the SRL model is for Indonesian students, therefore the focus of this research is to handle and compare various SRL models to build an SRL model that is appropriate to the situation of students in Indonesia.

\section{Methods}

This type of research is a review of the SRL model that critically studies and then looks at the application of the model in Indonesia. The criteria taken in the review of this model are models that have a theoretical and empirical background. The models analyzed are widely used actively until now, models by Boekaerts; Winne; Zimmerman; Efklides; Hadwin, Järvelä, and Miller; and Pintrich are included because they are widely used as a basis for various SRL studies. The models that will be examined further in this article are models from Boekaerts; Winne; Zimmerman; Efklides; Hadwin, Järvelä and Miller; and Pintrich with the consideration that these models are the basis of other SRL research and are still being developed today [31]. The research method used is to compare various SRL models that are often used by looking at quotations of SRL models in research journals. The Zimmerman model [4] was quoted as much as 6899 and in 2020 it was quoted 267 times, the Boekaerts model [30] was quoted as much as 1675 and in 2020, it was quoted as many as 66 times. The Winne and Hadwin model [33] was cited as many as 2029 and in 2020 cited 104 times. The Pintrich model [16] was quoted as many as 5374 and this year cited 209 times. Various reference sources used in this research were searched from Google Scholar.

Table 1. Pintrich's SRL Model by Pintrich

\begin{tabular}{|c|c|c|c|c|}
\hline \multirow[b]{2}{*}{ Phases } & \multicolumn{4}{|c|}{ Areas for Regulation } \\
\hline & Cognition & $\begin{array}{l}\text { Motivation/ } \\
\text { Affect }\end{array}$ & Behavior & Context \\
\hline $\begin{array}{c}1 . \\
\text { Forethought, } \\
\text { planning, \& } \\
\text { activation }\end{array}$ & $\begin{array}{l}\text { Target goal setting, prior } \\
\text { content knowledge } \\
\text { activation, \& metacognitive } \\
\text { knowledge activation }\end{array}$ & $\begin{array}{c}\text { Goal orientation adoption, } \\
\text { efficacy judgments, ease of } \\
\text { learning judgments, task value } \\
\text { activation, \& interest activation }\end{array}$ & $\begin{array}{l}\text { Time \& effort planning; } \\
\text { planning for } \\
\text { self-observations of } \\
\text { behavior }\end{array}$ & $\begin{array}{l}\text { Perceptions of task } \\
\text { \& perceptions of } \\
\text { context }\end{array}$ \\
\hline $\begin{array}{c}2 . \\
\text { Monitoring }\end{array}$ & $\begin{array}{l}\text { Metacognitive awareness } \\
\text { \& monitoring of cognition }\end{array}$ & $\begin{array}{l}\text { Awareness \& monitoring of } \\
\text { motivation \& affect }\end{array}$ & $\begin{array}{l}\text { Awareness \& monitoring } \\
\text { of effort, time use, need } \\
\text { for help }\end{array}$ & $\begin{array}{c}\text { Monitoring } \\
\text { changing task \& } \\
\text { context conditions }\end{array}$ \\
\hline $\begin{array}{c}3 . \\
\text { Control }\end{array}$ & $\begin{array}{l}\text { Selection \& adaptation of } \\
\text { cognitive strategies for } \\
\text { learning }\end{array}$ & $\begin{array}{l}\text { Selection \& adoption of } \\
\text { strategies for managing } \\
\text { motivation \& affect }\end{array}$ & $\begin{array}{c}\text { Self-observations of } \\
\text { behavior \& } \\
\text { increase/decrease effort }\end{array}$ & $\begin{array}{c}\text { Change/renegotiate } \\
\text { task \& change/leave } \\
\text { context }\end{array}$ \\
\hline $\begin{array}{c}4 . \\
\text { Reaction \& } \\
\text { Reflection }\end{array}$ & $\begin{array}{c}\text { Cognitive judgments \& } \\
\text { Attributions }\end{array}$ & $\begin{array}{l}\text { Affective reactions \& } \\
\text { Attributions }\end{array}$ & $\begin{array}{c}\text { Persist, give up, } \\
\text { help-seeking behavior, \& } \\
\text { choice behavior }\end{array}$ & $\begin{array}{l}\text { Evaluation of task \& } \\
\text { evaluative of context }\end{array}$ \\
\hline
\end{tabular}




\section{Results}

The results of PISA 2018 show that the abilities of Indonesian students are still far below average. This report shows that Indonesian students do not have the high ability on one subject, even the minimum ability is not. Based on the results of interviews conducted on 30 students aged 15-18 years, it is known that secondary students in Indonesia study because they are required to obtain the best grades. Students learn because they have to face exams, students do not know the benefits of learning, are accustomed to work and study according to the instructions and instructions of the teacher, do not have the initiative, are not accustomed to thinking, and learning objectives are unclear and abstract. The SRL models are made at the level of students ready and know what benefits will be obtained when they proceed with their learning. As mentioned by Boekaerts that most traditional classroom learning tends to be fragmented, indirect experience, driven by the goals set by the teacher. Learning experiences that are planned systematically and planned cannot attract students' interest, because it means that the information provided during the learning process in the classroom may not necessarily activate prior knowledge.

The Boekaerts; Winne; Zimmerman; Efklides; Hadwin, Järvelä and Miller; and Pintrich models in the preparation phase see students how to do forethought, how students analyze assignments and have self-motivation, goals to be achieved, how plans are made to achieve goals. The adjustable learning model is presented briefly and then expanded to include two new constructions, the student's natural goals and the goals made by the teacher. Adaptable Learning Model is a framework that allows each individual to explore interactions between intertwined aspects of SRL. Over time, a number of interrelated processes have been distinguished, including metacognitive, motivational, emotional, and action monitoring. Therefore, each individual needs a SRL model that can improve students' SRL skills, especially many traditional class students in Indonesia, who still depend on the teacher's role in learning. A simpler formulation that can support student-learning outcomes as follows. Knowing the condition of students, not just the conditions of the assignments but the conditions of student readiness to go through the learning process independently Students are further divided into, students with high and low SRL skills.

Students with high SRL skills can then go through the process of goal setting, planning, strategy, and reflection. Students with low SRL skills need more intervention from the teacher and facilitator. The first thing that needs to be done is to make students change their learning paradigms from learning because examinations become learning. They need to solve the problems they face because the core of SRL is how students determine their learning goals, understand student characteristics, and write their descriptions with detail. Second, accustoming students to think critically and use the Socratic Method in their learning process for students under the age of 15 years can be started with the method of tuning in from. Thirdly at the strategy stage, students begin to be able to monitor the progress of their learning process, already on the path to achieving goals, what to do if not yet, when they need help. The fourth stages of reflection, students do self-reflection to find out that the resulting learning products are in accordance with the learning objectives. Students also evaluate the learning they have done according to suggestions from teachers and peers. Furthermore, a simple SRL model resulting from the new formulation of this research can be shown as in Figure 7 below.

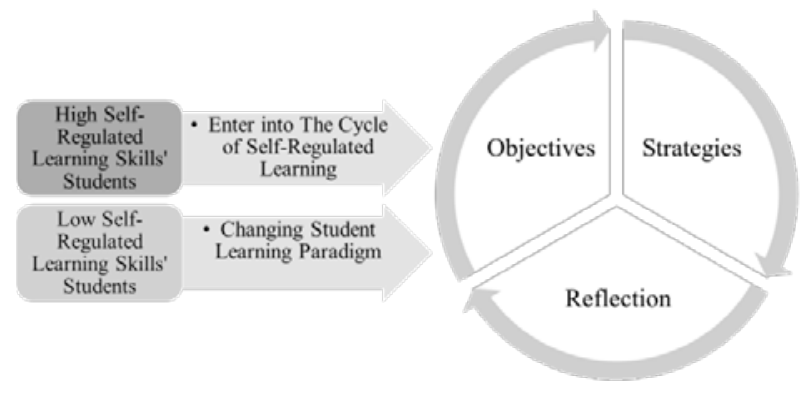

Figure 7. Simple SRL Model Scheme

Figure 7 shows the results of the synthesis of the four SRL models presented in the previous discussion. However, the four models of SRL have not answered questions about students who are accustomed to learning because of the test, because of the teacher, students who have no initiative and do not know why they have to learn. Therefore, before entering the SRL cycle, students are grouped into two, students with high and low SRL skills. This classification can be done with the contents of the questionnaire SRL, then categorized a score of 50\% down including low SRL skills, scores above 51\% including high SRL skills category. Students with high SRL skills can directly enter the SRL cycle. Meanwhile, students with low SRL need to be given an intervention by the teacher by first completing the student-learning paradigm. After this step is completed, students can then enter the SRL cycle.

There are three components to SRL, namely the objectives including the identification of learning material and planning. In addition, the togetherness of students and teachers can determine learning goals that are tailored to students' abilities. SRL is a goal-oriented process that emphasizes building, monitoring, and controlling learning can grow naturally. This includes cognitive knowledge, motivation, emotions, and social factors. Meanwhile, the next stage is about learning strategies taken to achieve goals and adapt to student competencies. In this stage, students see whether the strategies used are sufficient to achieve their learning goals, if not at what stage the obstacles occur what should be done later. Thus, a comparison of the SRL models that have been proposed by several experts can be stated in the following Table 2 . 
Table 2. Comparison of SRL Ideas

\begin{tabular}{|c|c|c|c|}
\hline Model & Preparatory Phase & Performance Phase & Appraisal Phase \\
\hline Boekaerts & $\begin{array}{l}\text { Identification, interpretation, } \\
\text { primary and secondary appraisal, } \\
\text { \& goal setting }\end{array}$ & Goal Striving & Performance feedback \\
\hline Efklides & Task representation & Cognitive processing, performance & Regulating \\
\hline Hadwin, Järvelä, \& Miller & Planning & Monitoring \& control & Regulating \\
\hline Pintrich & $\begin{array}{c}\text { Forethought, planning, \& } \\
\text { activation }\end{array}$ & Monitoring \& control & Reaction \& reflection \\
\hline Winne and Hadwin & $\begin{array}{l}\text { Task definition, goal setting, \& } \\
\text { planning }\end{array}$ & Applying tactics \& strategies & Adapting metacognition \\
\hline Zimmerman & $\begin{array}{c}\text { Forethought (task analysis \& } \\
\text { self-motivation) }\end{array}$ & $\begin{array}{c}\text { Performance (self-control \& } \\
\text { self-observation) }\end{array}$ & $\begin{array}{c}\text { Self-reflection (self-judgment \& } \\
\text { self-reaction) }\end{array}$ \\
\hline Synthesis of SRL Model & $\begin{array}{l}\text { Goal (goal orientation, student } \\
\text { beliefs, self-efficacy, \& test } \\
\text { anxiety) }\end{array}$ & $\begin{array}{l}\text { Strategy (self-efficacy, student } \\
\text { competencies, critical thinking, } \\
\text { metacognitive, \& creative) }\end{array}$ & $\begin{array}{l}\text { Reflection (self-evaluation \& } \\
\text { learn from the mistake) }\end{array}$ \\
\hline
\end{tabular}

\section{Discussion}

SRL students choose the most effective cognitive learning activities depending on learning assignments given in a broader context [36]. SRL students influence their cognitive and students who actively organize their learning so they engage in more effective strategies. Student progress during learning is the result of using their cognitive strategies $[44,45]$. This progress, used as input for further independent regulation through supervision [42]. SRL and the use of cognitive strategies form a cyclic process during learning [46]. The effect of SRL on the use of cognitive learning strategies is likely to explain why previous review studies consistently show that SRL is associated with higher student learning outcomes [47]. Cognitive strategies thus influence SRL on student learning outcomes; SRL successfully improves student-learning outcomes depending on how the intervention is carried out by the facilitator [48].

The importance of SRL for student learning outcomes, much research has been conducted on how student academic learning outcomes are influenced by interventions aimed at supporting student involvement in SRL activities [49,50]. Many ways to intervene in students' SRL. The facilitator must support student involvement in SRL activities, either by supporting the quality of student involvement in SRL activities, the amount of student involvement in SRL activities. Examples of SRL activities include telling students the importance of SRL activities, or encouraging students at the end of learning activities to reflect on the subject matter, on the tasks completed, and on the strategies, they use to learning [51].

A research result shows that independent learning correlates well with the academic achievement of 40 grade A students and 40 grade $\mathrm{D}$ students (the lowest academic level) [52]. SRL indicators are used to see the success of grade A group learning except for self-assessment. The results were not too different, the correlations of group A and group B were not significantly different on average by 0.7 , quite strong [52,53]. SRL is an important factor in student learning processes, especially students at the university level. They are generally assumed to have metacognitive skills to organize their learning. In addition, evidence shows that students who have academically SRL skills are more successful than students with low SRL skills [54]. A meta-analysis study conducted from 2005-2014 with 47 studies on the related of SRL with learning outcomes showed that metacognitive strategies and learning environments had the highest effect sizes.

Therefore, teachers need to implement metacognition tactics in the learning process in the classroom to improve students' abilities. Teachers should be given a professional development program on how to create a learning environment that supports the improvement of students' SRL skills, as well as prospective teachers to work to improve these skills [55,56]. The results of this meta-analysis also prove that teacher intervention as a facilitator to improve students' SRL skills is needed at all levels. Not only low levels such as primary or secondary and the university and workplace levels do not need [57]. Facilitator intervention is still needed to improve SRL skills.

\section{Conclusions}

SRL is a broad domain that provides a variety of sources for understanding variables that influence student learning and learning outcomes. During this time, SRL has been one of the main studies of research in education and psychology and currently in the field is a signal that its relevance will continue. Thus, the conclusion of this review is that the SRL model is useful as a source of learning at different levels. The teacher as a facilitator should have a variety of lists of SRL models so that they can adjust their interventions to improve these skills more effectively. Meanwhile, with the limitation of this research that includes a SRL model that is used as a research, reference only comes from four experts, the researcher or teacher can conduct a study similar to this research. Researchers or 
teachers can add the views of more expert SRL models, so they can be combined with the results of this research. Teachers can also directly implement the findings in this research to their students by adjusting the abilities and characteristics of students. Overall, the results of this research need to be followed up seriously because the SRL model supports learning in the present conditions that demand online, long-distance, and efficient learning.

\section{Acknowledgments}

We thank the lecturers of the Graduate School, Yogyakarta State University for guiding this research.

\section{REFERENCES}

[1] N. van Halem, C. van Klaveren, H. Drachsler, M. Schmitz, and I. Cornelisz, "Tracking patterns in self-regulated learning using students' self-reports and online trace data", Frontline Learning Research, vol. 8, no. 3, pp. 140-163, 2020.

[2] L. Tan, "Developing twenty-first-century competencies through the arts: a case study of a high performing secondary school band in Singapore", Asia Pacific Journal of Education, vol. 37, no. 4, pp. 472-482, 2017.

[3] M. D. Saputra, S. Joyoatmojo, D. K. Wardani, and K. B. Sangka, "Developing critical-thinking skills through the collaboration of the jigsaw model with problem-based learning model", International Journal of Instruction, vol. 12, no. 1, pp. 1077-1094, 2019.

[4] B. J. Zimmerman, "Self-regulated learning and academic achievement: An overview”, Educational psychologist, vol. 25, no. 1, pp. 3-17, 1990.

[5] C. H. Chen and C. Y. Su, "Using the Book Roll e-book system to promote self-regulated learning, self-efficacy and academic achievement for university students”, Journal of Educational Technology \& Society, vol. 22, no. 4, pp. 33-46, 2019.

[6] W. Guo, K. L. Lau, and J. Wei, "Teacher feedback and students' self-regulated learning in mathematics: A comparison between a high achieving and low-achieving secondary schools”, Studies in Educational Evaluation, vol. 63, pp. 48-58, 2019.

[7] A. Wigfield, S. L. Klauda, and J. Cambria, "Influences on the development of academic self-regulatory processes", Handbook of self-regulation of learning and performance, pp. 33-48, 2011.

[8] A. Alghamdi, A. C. Karpinski, A. Lepp, and J. Barkley, "Online and face-to-face classroom multitasking and academic performance: Moderated mediation with self-efficacy for self-regulated learning and gender", Computers in Human Behavior, vol. 102, pp. 214-222, 2020.

[9] K. Colthorpe, J. Ogiji, L. Ainscough, K. Zimbardi, and S. Anderson, "Effect of metacognitive prompts on undergraduate pharmacy students' self-regulated learning behavior", American Journal of Pharmaceutical Education, vol. 83, no. 4, pp. 34, 2019.

[10] I. Abdullah, B. Hudayana, P. M. Kutanegara, and A. Indiyanto, "Beyond school reach: Character education in three schools in Yogyakarta, Indonesia”, Journal of Educational and Social Research, vol. 9, no. 3, pp. 145, 2019.

[11] V. Hoogerheide, A. Renkl, L. Fiorella, F. Paas, and T. Van Gog, "Enhancing example-based learning: Teaching on video increases arousal and improves problem-solving performance", Journal of Educational Psychology, vol. 111, no. 1, pp. 45, 2019.

[12] S. Parveen, "Perception of female teachers in transferring peace concepts among adult students”, Pakistan Journal of Gender Studies, vol. 18, pp. 1-22, 2019.

[13] U. Widiati and N. Hayati, “Teacher professional education in Indonesia and ASEAN 2015: Lessons learned from English language teacher education programs”, ASEAN integration and the role of English language teaching, vol. 3, no. 2, pp. 121-148, 2015.

[14] S. Kim and M. Nor, "The effects of self-regulated learning strategies on preschool Children's self-efficacy and performance in early writing", International Journal of Education, vol. 11, no. 2, pp. 99-108, 2019.

[15] M. H. Cho and M. L. Heron, "Self-regulated learning: The role of motivation, emotion, and use of learning strategies in students' learning experiences in a self-paced online mathematics course”, Distance Education, vol. 36, no. 1, pp. 80-99, 2015.

[16] P. R. Pintrich, "The role of goal orientation in self-regulated learning”, Handbook of self-regulation, pp. 451-502, 2000.

[17] T. Sitzmann and K. Ely, “A meta-analysis of self-regulated learning in work-related training and educational attainment: What we know and where we need to go", Psychological Bulletin, vol. 137, no. 3, pp. 421-442, 2011.

[18] M. Puustinen and L. Pulkkinen, "Models of self-regulated learning: A review". Scandinavian Journal of Educational Research, vol. 45, no. 3, 269-286, 2001.

[19] V. Bonapersona, J. Kentrop, C. J. Van Lissa, R. Van Der Veen, M. Joels, and R. A. Sarabdjitsingh, "The behavioral phenotype of early life adversity: A 3-level meta-analysis of rodent studies”, Neuroscience \& Biobehavioral Reviews, vol. 102, pp. 299-307, 2019.

[20] I. Roll and P. H. Winne, "Understanding, evaluating, and supporting self-regulated learning using learning analytics", Journal of Learning Analytics, vol. 2, no. 1, pp. 7-12, 2015.

[21] B. J. Zimmerman and D. H. Schunk, "Motivational sources and outcomes of self-regulated learning and performance", Handbook of self-regulation of learning and performance, vol. 5, no. 3, pp. 49-64, 2011.

[22] A. M. Cazan, "Self-regulated learning strategies-predictors of academic adjustment", Procedia-Social and Behavioral Sciences, vol. 33, pp. 104-108, 2012.

[23] P. H. Winne and N. E. Perry, "Measuring self-regulated learning”, Handbook of self-regulation, pp. 531-566, 2000. 
[24] L. S. Teng and L. J. Zhang, "Effects of motivational regulation strategies on writing performance: A mediation model of self-regulated learning of writing in English as a second/foreign language", Metacognition and Learning, vol. 13, no. 2, pp. 213-240, 2018.

[25] A. Bandura, "Social cognitive theory of self-regulation", Organizational Behavior and Human Decision Processes, vol. 50, pp. 248-287, 1991.

[26] R. F. Kizilcec, M. Pérez-Sanagustín, and J. J. Maldonado, "Self-regulated learning strategies predict learner behavior and goal attainment in massive open online courses", Computers \& Education, vol. 104, pp. 18-33, 2017.

[27] E. Vrieling, S. Stijnen, and T. Bastiaens, "Successful learning: Balancing self-regulation with instructional planning", Teaching in Higher Education, vol. 23, no. 6, pp. 685-700, 2018.

[28] Z. Gan, F. Liu, and C. C. R. Yang, "Student teachers' self-efficacy for instructing self-regulated learning in the classroom”, Journal of Education for Teaching, vol. 46, no. 1, pp. 120-123, 2020.

[29] I. Rissanen, E. Kuusisto, M. Tuominen, and K. Tirri, "In search of a growth mindset pedagogy: A case study of one teacher's classroom practices in a finish elementary school", Teaching and Teacher Education, vol. 77, pp. 204-213, 2019.

[30] M. Boekaerts, "Cognitive load and self-regulation: Attempts to build a bridge", Learning and Instruction, vol. 51, pp. 90-97, 2017.

[31] E. Panadero, J. Klug, and S. Järvelä, "The third wave of measurement in the self-regulated learning field: When measurement and intervention come hand in hand", Scandinavian Journal of Educational Research, vol. 60, no. 6, pp. 723-735, 2015.

[32] K. Smit, C. J. de Brabander, M. Boekaerts, and R. L. Martens, "The self-regulation of motivation: Motivational strategies as a mediator between motivational beliefs and engagement for learning", International Journal of Educational Research, vol. 82, pp. 124-134, 2017.

[33] P. H. Winne and A. F. Hadwin, "Study: Tracing and supporting self-regulated learning on the internet", International handbook of metacognition and learning technologies, pp. 293-308, 2013.

[34] K. M. Law, S. Geng, and T. Li, "Student enrollment, motivation and learning performance in a blended learning environment: The mediating effects of social, teaching, and cognitive presence”, Computers \& Education, vol. 136, pp. $1-12,2019$.

[35] M. Taub, R. Sawyer, J. Lester, and R. Azevedo, “The impact of contextualized emotions on self-regulated learning and scientific reasoning during learning with a game-based learning environment", International Journal of Artificial Intelligence in Education, vol. 30, no. 1, pp. 97-120, 2020.

[36] P. H. Winne, "Issues in researching self-regulated learning as patterns of events", Metacognition and Learning, vol. 9, no. 2, pp. 229-237, 2014.

[37] E. Panadero, "A review of self-regulated learning: Six models and four directions for research”, Frontiers in
Psychology, vol. 8, no. 422, pp. 1-28, 2017.

[38] A. Efklides, "Interactions of metacognition with motivation and affect in self-regulated learning: The MASRL model”, Educational psychologist, vol. 46, no. 1, pp. 6-25, 2011.

[39] B. Rahmad, S. Dwi, and M. Ika, "The analysis of self-regulation learning on elementary schools at the rural area in Indonesia", Universal Journal of Educational Research, vol. 8, no. 2, pp. 395-401, 2020.

[40] A. Hadwin, S. Järvelä, and M. Miller, "Self-regulation, co-regulation, and shared regulation in collaborative learning environments”, In D. H. Schunk and J. A. Greene (Eds.), Educational psychology handbook series. Handbook of self-regulation of learning and performance, pp. 83-106). Routledge/Taylor \& Francis Group, 2018.

[41] M. Koivuniemi, E. Panadero, J. Malmberg, and S. Järvelä, "Higher education students' learning challenges and regulatory skills in different learning situations/Desafíos de aprendizaje y habilidades de regulación en distintas situaciones de aprendizaje en estudiantes de educación superior”, Infancia y Aprendizaje, vol. 40, no. 1, pp. 19-55, 2017.

[42] P. R. Pintrich and J. L. Blazevski, “Applications of a model of goal orientation and self-regulated learning to individuals with learning problems”, International review of research in mental retardation, vol. 28, no. 1, pp. 31-83, 2004.

[43] B. Çetin, “The influence of Pintrich’s self-regulated learning model on elementary teacher candidates in a life science course”, Journal of Education and Training Studies, vol. 5, no. 8, pp. 30-36, 2017.

[44] A. Ben-Eliyahu, "Individual differences and learning contexts: A self-regulated learning perspective”, Teachers College Record, vol. 119, no. 13, pp. 1-8, 2017.

[45] J. Dunlosky, K. A. Rawson, E. J. Marsh, M. J. Nathan, and D. T. Willingham, “Improving students' learning with effective learning techniques: Promising directions from cognitive and educational psychology”, Psychological Science in the Public Interest, Supplement, vol. 14, no. 1, pp. 4-58, 2013.

[46] Y. Rahmawati, S. F. Ramadhani, and Afrizal, "Developing students' critical thinking: A STEAM project for chemistry learning. Universal Journal of Educational Research, vol. 8, no. 1, pp. 72-82, 2020.

[47] G. L. Callan and T. J. Cleary, "Examining cyclical phase relations and predictive influences of self-regulated learning processes on mathematics task performance”, Metacognition and Learning, vol. 14, no. 1, pp. 43-63, 2019.

[48] M. de Bruijn-Smolders, C. F. Timmers, J. C. L. Gawke, W. Schoonman, and M. P. Born, "Effective self-regulatory processes in higher education: research findings and future directions. A systematic review", Studies in Higher Education, vol. 41, no. 1, pp. 139-158, 2016.

[49] R. S. Jansen, A. Van Leeuwen, J. Janssen, S. Jak, and L. Kester, "Self-regulated learning partially mediates the effect of self-regulated learning interventions on achievement in higher education: A meta-analysis”, Educational Research Review, vol. 28, pp. 100292, 2019.

[50] J. Broadbent and W. L. Poon, "Self-regulated learning strategies \& academic achievement in online higher 
education learning environments: A systematic review", The Internet and Higher Education, vol. 27, pp. 1-13, 2015.

[51] H. Putranta and J. Jumadi, "Physics teacher efforts of Islamic high school in Yogyakarta to minimize students' anxiety when facing the assessment of physics learning outcomes”, Journal for the Education of Gifted Young Scientists, vol. 7, no. 2, pp. 119-136, 2019.

[52] D. Beard, D. Schweiger, and K. Surendran, "Integrating soft skills assessment through university, college, and programmatic efforts at an AACSB accredited institution", Journal of Information Systems Education, vol. 19, no. 2, pp. 11, 2019.

[53] B. J. Zimmerman and M. M. Pons, "Development of a structured interview for assessing student use of self-regulated learning strategies", American educational research journal, vol. 23, no. 4, pp. 614-628, 1986.
[54] J. Antonelli, S. J. Jones, A. B. Burridge, and J. Hawkins, "Understanding the self-regulated learning characteristics of first-generation college students", Journal of College Student Development, vol. 61, no. 1, pp. 67-83, 2020.

[55] S. Arifin, H. Retnawati, J. Mailool, and H. Putranta, “The factors that influence of reading ability the Hijaiyah alphabet on pre-school children”, Journal for the Education of Gifted Young Scientists, vol. 8, no. 2, pp. 667-680, 2020.

[56] B. Ergen and S. Kanadli, "The effect of self-regulated learning strategies on academic achievement: A meta-analysis study”, Eurasian Journal of Educational Research, vol. 17, no. 69, pp. 55-74, 2017.

[57] S. Steenbergen-Hu, P. Olszewski-Kubilius, and E. Calvert, "The effectiveness of current interventions to reverse the underachievement of gifted students: Findings of a meta-analysis and systematic review", Gifted Child Quarterly, vol. 64, no. 2, pp. 132-165, 2020. 